\title{
A MAGYAR FIATAL FELNŐTTEK SPORTOLÁSI SZOKÁSAI ÉS A SPORT MOTIVÁCIÓJUK ALAKULÁSA
}

Kinczel Antonia - Bácsné Bába Éva - Molnár Anikó - Laoues-Czimbalmos Nóra Müller Anetta

\section{Összefoglalás}

A fiatal felnöttek sportolási szokásainak vizsgálatára online kérdöivet szerkeszettünk, melyet online felületeken, social media használatával töltettünk ki $(\mathrm{N}=481)$. A válaszokból csak a fiatal felnöttek adatait szürtüle le, melyet feldolgoztunk a tanulmányban. Alapstatisztikát, gyakoriságot számitottunk, az összefüggések vizsgálatára Chi2 próbát alkalmaztunk. Az eredményeink azt igazolták, hogy a lakóbely (falu, város, föváros) tekintetében a sportolási helyszinek prefenciäja és a sportmotiváció eltéröen alakult. A falun élók, 31,5\%-a nyilatkozta azt, hogy otthon sportol, mig a városi válaszadóknak csupán 17\%-a, mely igen erós szignifikáns eltérést mutatott $(p=0,000)$. A városi válaszadók 17,4\%-a fitnesz-wellness központokba sportol, mely szignifikénsan magasabb, mint a falusi válaszadók aránya (8,7\%). Ugyancsak a városi fiatal felnôttek (18,4\%) részesitike elónyben az egyesületi sportolási formát a falusiakekal $(15,2 \%)$ szemben $(p<0,05)$. A fiatalok sportmotivációjában az, egészség, boldogság, vonzó külsö és a szórakoztató funkció kapta a legmagasabb értéket. A fóvárosi fiatalok sportmotivációjában az egészség és társaság, a városi fiatalok motivációjában a sqórakozás, boldogság önmagam megismerése, míg a falusi fiatalok esetében a motivációban a von ₹ó küllalak és a mások elvárása srignifikánsan magasabb átlagértéket kapott a többi csoporthoz képest.

Kulcsszavak: aktiv életmód, sqabadidósport, prevenció

JEL: Z2

\section{SPORTS HABITS OF HUNGARIAN YOUNG ADULTS AND THE DEVELOPMENT OF THEIR SPORTS MOTIVATION}

\begin{abstract}
To examine the sporting habits of young adults, we compiled an online questionnaire, which in turn was shared on online social media platforms in order to gather as many fill outs as possible $(N=481)$. From the responses only data from young adults were filtered out and processed in this study. Basic statistics, frequencies were calculated, and the Chi2 test was used to examine the correlations in the database. Our results confirmed that the preference of sporting venues and the motivation to exercise developed differently in terms of place of residence (village, city, capital). $31.5 \%$ of the rural population while only $17 \%$ of the urban respondents stated that they exercise at home, which showed a very strong significant difference $(p=0.000) .17 .4 \%$ of urban respondents play sports in wellness centers, which is significantly bigher than the proportion of rural respondents (8.7\%). Urban young adults (18.4\%) also prefer the associational form of sport over villagers $(15.2 \%)(p<0.05)$. With regards to the sports motivation among those young people living in the capital, health and community, among those living in big cities fun, bappiness and self-awareness, while those living in villages appearance and the expectations of others scored the highest.
\end{abstract}

Keywords: active lifestyle, leisure sports, prevention

JEL:Z2 


\section{Bevezetés}

Napjainkban a szabadidő értékként jelenik meg, melyben azoknak a szabadidős tevékenységeknek a szerepe értékelődik fel, melyek a kikapcsolódáson és szórakozáson túl hozzájárulnak az emberek egészségének és munkaképességének megtartásához és a preventív szemlélet jegyében az egészséges életmódhoz.

A szabadidő eltöltésével foglalkozó hazai (Laoues et al. 2019; Lengyel, 2016; Lenténé et al. 2018a, b, 2019; Bocsi, 2019) és nemzetközi (Verghese et al. 2003; Law et al. 2006; Fletcher et al. 2003; Agahi-Parker, 2008) szakirodalmak száma igen jelentős, mely különböző témaspecifikumokra fókuszál és melyek száma egyre bővül. A szabadidős tevékenységek trendjeivel foglalkozó kutatások felhívják a figyelmet arra, hogy az aktív tevékenységek között olyan sporttevékenységek a népszerủek, melyek szórakoztatóak, melyek élményt és kihívást nyújtanak a fogyasztónak vagy a játékos jelleg dominál (Mező et al. 2018). A sportos szabadidő eltöltésben az outdoor irányzatok (Bujdosó-Dávid, 2013; Boda, 2018) mellett megjelennek az egészségmegőrzéssel kapcsolatos fitnesz-wellness (Lenténé et al. 2019; Molnár, 2019; Müller et al. 2019; Thompson, 2020), mindfullness (Lengyel et al. 2019) trendek és a különböző relaxációs módszerek is (Molnár, 2012).

A fiatal felnőttek sportolási szokásainak és aktivitásának vizsgálata igen fontos terület, hiszen ebben a korban még aktív életet élnek és fontos, hogy minél kevesebb legyen azoknak a száma, akik abbahagyják a sportot, hiszen a kutatások is bizonyítják, hogy az életkor előrehaladtával egyre inkább inaktív életet élnek a felnőttek és a sportolók aránya is csökken.

\section{Anyag és módszer}

A fiatal felnőttek sportolási szokásainak vizsgálatára online kérdőívet szerkesztettünk, melyet online felületeken, social media használatával töltettünk ki. A válaszokból csak a fiatal felnőttek adatait szűrtük le, melyet feldolgoztunk a tanulmányban. Alapstatisztikát, gyakoriságot számítottunk, az összefüggések vizsgálatára Chi2 próbát alkalmaztunk.

\section{A minta bemutatása}

A vizsgálatunk 481 fő fiatal felnőtt válaszait dolgozza fel és elemzi. A válaszadók 70,9\%-a nő (341 fö) és csupán 29,1\%-a férfi (140 fö). Ebből is megfigyelhetô, hogy a nôk valamennyivel nyitottabbak és több dologra figyelnek, hiszen valószínúleg sok férfi figyelmen kívül hagyta ezt a kérdőívet. A legtöbb kitöltő, 40,3\%-uk (194 fő) városban él, 34,7\%-uk (167 fó) megyeszékhelyen, 19,1\%-uk faluban, 5,8\%-uknak pedig fővárosban van a lakóhelyük.

A kérdőívet kitöltők életkori kategória szerinti csoportosítását az első ábra szemlélteti, méghozzá a következő képpen: 81,9\%-uk (394 fö) 19-25 év közötti, 6,8\%-uk (33 fó) 18 év alatti, 5,0\%-uk (24 fő) 26-30 fő közötti, 1,5\%-uk (7 fő) 31-35 év közötti, a többi fennmaradó 4,8\%-uk pedig 36 év fölötti. 


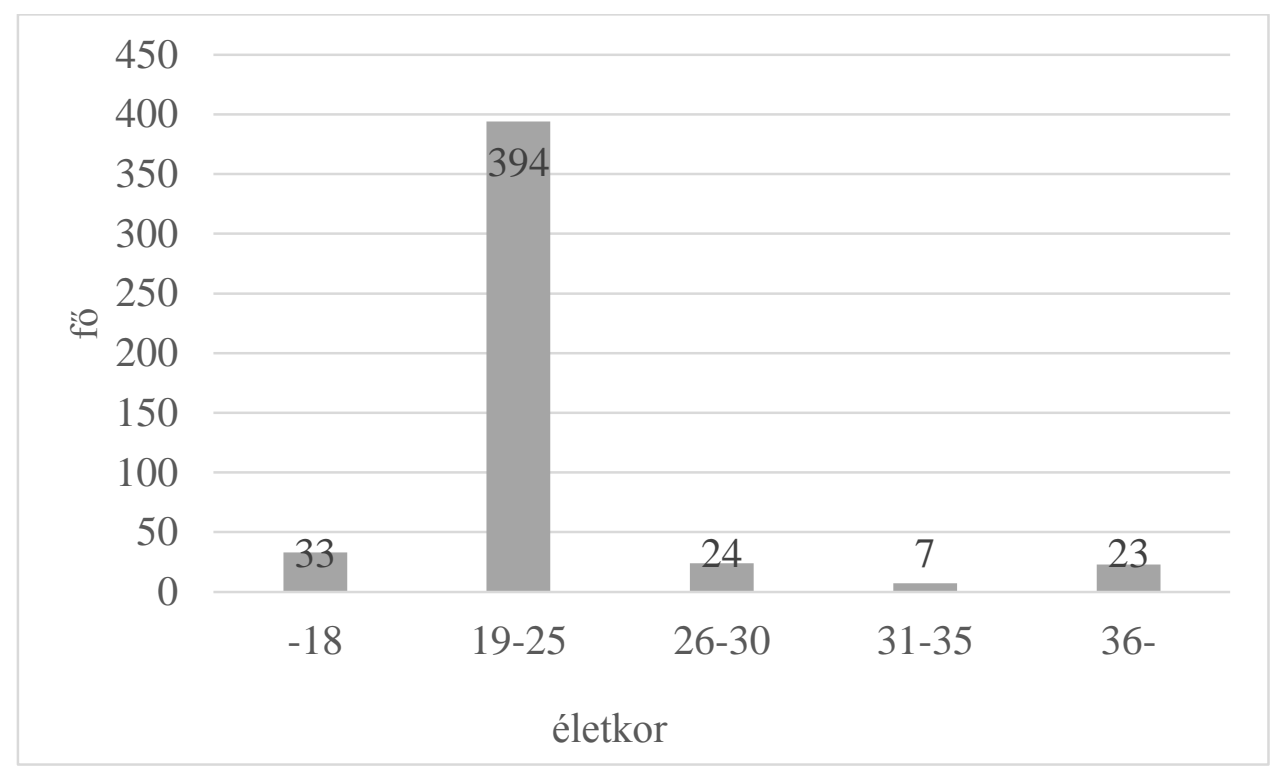

1. ábra. A válaszadók életkor szerinti megoszlása

$\mathrm{Az}$ egy főre eső nettó jövedelem alapján négy csoportra bontottuk az alanyokat, annak függvényében, hogy mennyi a keresetük. Magyarországon, a kitöltők közül, az egy főre jutó nettó havi jövedelem 38,7\%-nak (186 fö) 101 000-150 000 ezer Ft közötti összeg. 28,7\%-nak (138 fö) 151 000- 250000 Ft közötti a nettó jövedelem, 18,7\%-nak (90fö) 100000 Ft alatti és csak 12,7\%nak (61 fó) 250000 Ft feletti a jövedelem.

Ahhoz, hogy a későbbiekben következtetéseket, összefüggéseket tudjunk elemezni, megkérdeztük a válaszadókat, hogy ki milyen jellegű munkát végez. 83,4\%-a (401 fó) a kitöltőknek tanuló, vagyis legtöbbet ülő helyzetben vannak, 10,2\%-a (49 fö) ülőmunkát végez, 5,2\%-a vegyes (ülő és fizikai munkát is végez) (25 fö), 1,2\%-a pedig (6 fő) csak fizikai munkát végez (1. táblázat). Ezekből az adatokból azt feltételeztük, hogy a legtöbben a szabadidejüket aktívan, sok testmozgással töltik, de sajnos, mint kiderült a többi válaszból, feltételezésünk nem volt teljes mértékben igaz, mivel a legtöbben szívesebben végeznek passzív rekreációs tevékenységeket a fennmaradó idejükben. Több kutatás is megerősíti, hogy napjainkban, a virtuális világban és online térben töltött szabadidős tevékenységek is erősödnek (Galán et al., 2018; Baranyi - Ráthonyi, 2019).

\section{1. táblázat. A válaszadók felosztása annak függvényében, hogy milyen jellegű munkát} végeznek

\begin{tabular}{|l|l|l|}
\hline Milyen jellegű munkát végez? & \multicolumn{1}{|c|}{ Fő } & $\begin{array}{c}\text { Százalék } \\
(\%)\end{array}$ \\
\hline Tanuló vagyok & 401 & 83,4 \\
\hline Ülómunka & 49 & 10,2 \\
\hline Fizikai munka & 6 & 1,2 \\
\hline $\begin{array}{l}\text { Vegyes (ülő és fizikai munkát is } \\
\text { végzek) }\end{array}$ & 25 & 5,2 \\
\hline Összesen & 481 & 100 \\
\hline
\end{tabular}




\section{Eredmények}

Megkérdeztük a kutatásban részt vett személyeket, hogy végeznek-e a testnevelés órán kívül aktív testmozgást, melynek hossza minimum fél óra. 71,1\%-uk (342fő) azt válaszolta, hogy igen, míg a fennmaradó 28,9\% (139 fö) válasza a nem volt. Tovább boncolgattuk a kérdést, számszerūen rákérdeztünk arra, hogy egy héten átlagosan hány órát sportolnak. Beleszámítva azt is, hogy mennyit sétálnak, kocognak, kerékpároznak. 29,5\%-uk (142 fö) 2-3 órát sportol hetente, 23,1\%-uk (111 fö) 3-5 órát végez aktív testmozgást hetente, 13,3\%-uk (64 fő) 5-8 órát tölt testmozgással, 8,5\%-uk (41 fő) 8-10 órát, 6,0\%-uk (29 fő), pedig több, mint 10 órát sportol hetente. 19,5\%-uk (94 fö) azt válaszolta, hogy nem sportol, néha sétál, kerékpározik, ami számszerúen csak egy óra aktív testmozgást jelent hetente (2. táblázat).

\section{2. táblázat. A kitöltők sportolással töltött ideje egy héten}

\begin{tabular}{|l|l|l|}
\hline $\begin{array}{l}\text { Egy héten átlagosan hány órát } \\
\text { sportolnak? }\end{array}$ & Fơ & $\begin{array}{l}\text { Százalék } \\
(\%)\end{array}$ \\
\hline Hetente 2-3 órát sportolok & 142 & 29,5 \\
\hline Hetente 3-5 órát sportolok & 111 & 23,1 \\
\hline Hetente 5-8 órát sportolok & 64 & 13,3 \\
\hline Hetente 8-10 órát sportolok & 41 & 8,5 \\
\hline $\begin{array}{l}\text { Több mint 10 órát sportolok } \\
\text { hetente }\end{array}$ & 29 & 6,0 \\
\hline $\begin{array}{l}\text { Nem sportolok. Néha sétálok, } \\
\text { kerékpározok, szóval maximum } \\
1 \text { órát }\end{array}$ & 94 & 19,5 \\
\hline Összesen & 481 & 100 \\
\hline
\end{tabular}

A legkedveltebb sportolási helyszíneknek a természetben lévő sportpályák, parkok minősültek, az emberek 22,2\%-uk (107 fö) a legszívesebben ott sportol. Sokan vannak, akiknek kevés idő jut a sportra, így ők gyorsan, otthon végzik el a testmozgást (20,6\%, 99 fö). 20,0\%-uk az embereknek (96 fő) fitness-wellness központba jár el sportolni, 14,3\%-uk (69 fö) az iskolában/ egyetemen/ munkahelyen sportol, 13,5\%-uk (65 fő) egyesületen belül, 9,4\%-uk (45 fö) pedig iskolába/ egyetemre/ munkahelyre menet sportol (3. táblázat). 
3. táblázat. Legkedveltebb sportolási helyszínek

\begin{tabular}{|l|l|l|}
\hline Hol szokott sportolni? & Fô & Százalék (\%) \\
\hline Egyesületben & 107 & 22,2 \\
\hline Fitness-wellness központban & 69 & 14,3 \\
\hline $\begin{array}{l}\text { Iskolába/egyetemre/munkába } \\
\text { menet }\end{array}$ & 45 & 9,4 \\
\hline Iskolában/egyetemen/munkahelyen & 65 & 13,5 \\
\hline Otthon & 99 & 20,6 \\
\hline Szabadban, parkokban & 107 & 22,2 \\
\hline Összesen & 481 & 100 \\
\hline
\end{tabular}

Amennyiben a sportolás színtereit a falusi és városi válaszadók esetében megvizsgáltuk Chi2 próbával, úgy azt az eredményt kaptuk, hogy a falun élôk 31,5\%-a nyilatkozta azt, hogy otthon sportol, míg a városi válaszadóknak csupán 17\%-a, mely igen erős szignifikáns eltérést mutatott $(\mathrm{p}=0,000)$. A városi válaszadók 17,4\%-a fitnesz-wellness központokba sportol, mely szignifikánsan magasabb, mint a falusi válaszadók válasza $(8,7 \%)$. Ugyancsak a városi fiatal felnôttek $(18,4 \%)$ részesítik előnyben az egyesületi sportolási formát a falusiakkal $(15,2 \%)$ szemben $(p<0,05)$.

Az Eurobarométer $(2014,2018)$ adatai szerint, az unió lakosságának 40\% -a parkokban, 32\%-a otthon és $23 \%$-uk az otthon és az iskola vagy munkahely közötti úton végzi a szabadidős sportot, mely eredmények a 2014-ben közölt Eurobarométer adataihoz hasonlóak, bár növekedés tapasztalható a sportközpontban sportoló vagy fizikai tevékenységet folytató arányában $(+4$ százalékpont), míg az otthon sportolók aránya némileg csökkenést mutatott (-4 pp).

Az Uniós felmérés (Eurobarométer, 2018) azt is kimutatta, hogy az otthoni sport vagy fizikai tevékenység népszerủ a kelet-európai országokban. Ezekben az országokban ugyanis a válaszadók több mint a fele nevesítette ezt a kategóriát, a szlovákok $62 \%$-a, a románok $60 \%$-a, a magyarok és a litvánok egyaránt 59\%-a és a lettek 54\%-a. ezzel szemben a mi kutatásunk azt mutatja, hogy a fiatal felnőttek csupán 20,6\%-a végzi otthon a szabadidősport tevékenységét, mivel a fiataloknak a közösség a barátokkal való találkozás sokkal fontosabb, mint az idősebb korosztály esetében, melyet a sportmotivációs eredményeink is megerősítenek a 4. táblázatban.

\section{4. táblázat. Sportmotiváció alakulása a felmért mintában (1= egyáltalán nem fontos, $7=$} leginkább fontos)

\begin{tabular}{|l|l|l|l|l|}
\hline Okok & Átlag & Szórás & P érték & Domináló csoport \\
\hline egészség & 5,76 & 1,62 & 0,01 & fóvárosi \\
\hline boldogság külsó & 5,58 & 1,75 & 0,02 & városi \\
\hline $\begin{array}{l}\text { vonzó } \\
\text { megjelenés }\end{array}$ & 5,44 & 1,83 & 0,00 & falusi \\
\hline $\begin{array}{l}\text { szórakoztató } \\
\text { funkció }\end{array}$ & 5,19 & 1,87 & 0,001 & városi \\
\hline $\begin{array}{l}\text { Önmagam } \\
\text { megismerése }\end{array}$ & 4,9 & 1,91 & 0,00 & városi \\
\hline társaság & 3,65 & 2,14 & 0,00 & fóvárosi \\
\hline mások elvárják & 1,75 & 1,50 & 0,03 & falusi \\
\hline
\end{tabular}


A fiatal felnőttek sportmotivációs tényezőit figyelhetjük meg a táblázatban. Az egészség kapta a legmagasabb átlagértéket az 1-7-es skálán. Ez megerősíti az egészségközpontú rekreációs irányzatok trendjeit a fiatal felnőtt korosztály körében is (Müller et al. 2017). Az egészség megőrzése, mint legfőbb motivációs tényező a fóvárosi fiatalok mintájában kapta a legmagasabb átlagértéket, azaz nekik a szabadidős sportolás motivációjában ez dominánsan jelentkezik, szignifikánsan magasabb átlagot tapasztaltunk, mint a falusi vagy más városokban lakó fiatalok mintájában. Oka lehet, hogy a fővárosban lakók sokkal kevesebb aktivitást mutathatnak a közlekedés, házimunka kapcsán a lakókörnyezetéből adódóan. Korábbi hazai reprezentatív nagymintás ( $\mathrm{n}=1295)$ fizikai aktivitást (IPAQ-long verzióval) mérô kutatás igazolta, hogy a magas aktivitású emberek nagyobb arányban éltek falvakban (70\%), mint a fövárosban (54,9\%) és a megyei városokban (59,6\%). Mivel a falusi életmód több házimunkát, kertészkedést és a gyalogos vagy kerékpáros közlekedésben való részvételt jelent a mindennapi életben, mint a városi környezetben (Bácsné et al. 2020), így a városiaknak az egészségük megtartásához több szabadidős sportaktivitást kell végezni.

A boldogság, mint motivációs faktor is jelentős átlagértéket mutatott $(5,58)$, és a szórakoztató funkció is $(5,19)$, mely a városi fiatalok esetében szignifikánsan erősebben jelentkező motivációnak bizonyult. A szabadidős tevékenységek során a trendek is azt mutatják, hogy a fiatal felnőttek körében az extrém és outdoor irányzatok a szórakoztató vagy élménykereső elemei miatt is népszerűek (Müller et al. 2018, 2019)

A külsô megjelenés (átlag= $=5,44)$ szintén fontos motivációnak bizonyult az általunk vizsgált fiatal felnőtt mintában, azonban ez a motiváció a falun lakó fiatalok esetében szignifikánsan erősebbnek bizonyult, mint a városlakó fiatalok esetében. Az önmagam megismerése a városi mintában, a társaság a fôvárosi mintában mutatott szignifikánsan magasabb eredményt. A fővárosban a magányos, vagy elmagányosodó lakosság számára a sport közösségi funkciója erősebb, mely magyarázható azzal, hogy a falvakban, kisvárosokban élők közelebb vannak egymáshoz, az emberi kapcsolatok erősebbek, a találkozások száma gyakoribb.

A „mások elvárják tőlem” motiváció (átlag=1,75) a legalacsonyabb átlagértéket kapta, mely azt jelzi, hogy ez a legkevésbé fontos a vizsgált mintában és itt tapasztaltuk a legegységesebb válaszokat, hiszen a szórásérték ennél a válasznál volt a legkisebb. A mások elvárása motiváció azonban a falusi fiatalok számára fontosabbnak bizonyult, mint a városi, fővárosi faitaloknak, mivel ebben az esetben is szignifikáns volt az eltérés.

Amennyiben összehasonlítjuk az eredményeinket más kutatásokkal, azt tapasztalhatjuk, hogy az Unió felnőtt lakosságának sportmotivációjában az egészség dominál (62\%), melyet a fitnesz szint növelése (40\%), a relaxáció (36\%) majd az öröm, szórakozás $(30 \%)$ követett az Eurobarométer 2014-es felmérésében, mely 27 EU-s ország átlagértékeit mutatta. Ebben a kutatásban a magyar felnőtt lakosság csak 39\%-a jelölte az egészséget, mint motivációt és csupán 7\%-a az örömet és szórakozást, azaz a hazai értékek ebben a két motivációban az uniós átlag alatt szerepeltek. A 2018as Eurobarométer adatiban némi változás történt, azonban a főbb motivációs tényezők nem változtak: az egészség az első helyen maradt, azonban 54\%-ra csökkent (-8\%pont) a korábbi 2014es Eurobarométer felméréshez képest, a fitnesz szint javítása növekedett $7 \%$ ponttal, így a válaszadók 47\%-a jelölte motivációs tényezőként, az öröm, szórakozás 30\%-os értéke maradt. magyar mintában az öröm és szórakoztató tevékenység motivációja erôsödött, hiszen 7\%-ról 11\%ra növekedett (Eurobarométer, 2014, 2018).

Az eurobarométer (2018) szociodemográfiai adatai alapján megállapította, hogy az általunk is vizsgált fiatal felnőttek mintájában bizonyos motivációk markánsabban jelennek meg: a fizikai megjelenés javítása a 15-24 évesek 29\% -a nevesítette okként, míg az 55 évesnél idősebbeknek csupán 12\%-a. A szórakozás, vagy a szabadidősport szórakoztató funkciója szintén a fiatalabb 
generáció értékrendjébe jelenik meg markánsabban, hiszen a 15-24 évesek 44\% -a, míg az 55 évnél idősebbeknek csupán 23\%-a jelölte sportmotivációnak. A társaság, a barátokkal lenni, azaz a közösségi szerepe szintén a fiatal felnőttek számára volt fontosabb, akiknek a 33\%-a, míg az idôsebbeknek csupán 15\% -a nevesítette (Eurobarométer, 2018).

Amennyiben a saját kutatásunk eredményeit nézzük a magyar fiatal felnőtt mintában, úgy megerősíthetjük, hogy az egészségmegőrzés az első helyen szerepel, majd a boldogság, külső megjelenés és a szórakoztató funkció dominál, mely az Uniós vagy hazai trendekkel mutat hasonlóságot.

Bizonyított tény, hogy a rendszeres testedzés és fizikai aktivitás pozitívan hat az emberi egészségre, hiszen számos úgynevezett életmódfüggő betegség kialakulásának a kockázatát csökkenti (Manson, 1999; Kruk, 2009; Comistek et al. 2013; Apor, 2011) Ezekkel a tényekkel az általunk vizsgált fiatal felnőttek emberek többsége tisztában is van, hiszen 97,3\%-uk (468 fó) azt válaszolta, hogy tudja, hogy a sport pozitívan hat az egészségre és azt is milyen pozitív előnyei vannak a sportnak. Ez nem meglepő, hiszen a válaszadók sportmotivációjában az első helyen az egészséggel kapcsolatos motiváció áll.

A testnevelési és sportprogramok ösztönzését (Hidvégi et al., 2017; Müller-Bácsné, 2018) emeli ki több szerző, mivel a sport elősegíti a kikapcsolódást, a felfrissülést, a jobb közérzetet biztosít, ezért segít javítani az emberek közérzetén, csökkenti a stressz szintet és prevenciós eszközként funkcionál számos életmódfüggő betegség esetében. Ezeket a pozitív hatásokat figyelembe véve válaszolhatták azt a kitöltők, hogy ha lesz gyermekük, akkor támogatni, bíztatni fogják őket a sportolásra.

Sok személynek hiányzik a kellő motiváció és emiatt nem mennek el sportolni. Megkérdeztük a kitöltőket, hogy az ő életükben van-e olyan személy, akivel szívesen elmennek sportolni. 76,7\%-uk számára (369 fö) van olyan személy, aki tudja őket motiválni a testmozgásra, azonban 23,3\%-uk (111 fó) életében nincs olyan személy, aki tudná buzdítani őket az aktívabb életre. Kevésnek tűnhet ez a 23,3\%, azonban nem szabad figyelmen kívül hagynunk. Ha több olyan személy lenne a városokban, falvakban, aki csoportos edzéseket tartanának, bizonyára e 111 személy közül is lenne, aki részt venne rajta. Azt is megkérdeztük tőlük, hogy milyen elhatározásból, kinek/kiknek köszönhetően kezdtek el sportolni. A legtöbben, 32,0\% (154 fő), azt vallották, hogy saját elhatározásból kezdték el az aktív testmozgást, de másoknál befolyásoló szerepet játszottak főleg a szülők (17,7\%, 85 fö) és a barátok (25,4\%, 122 fö), melyet jól szemléltet a második ábra is. A testvér, edző, tanár, orvos kisebb mértékben váltak motiváló tényezőkké a kitöltők életében (2. ábra). 
Kinczel A. - Bácsné Bába É. - Molnár A. - Laoues-Czimbalmos N. - Müller A.

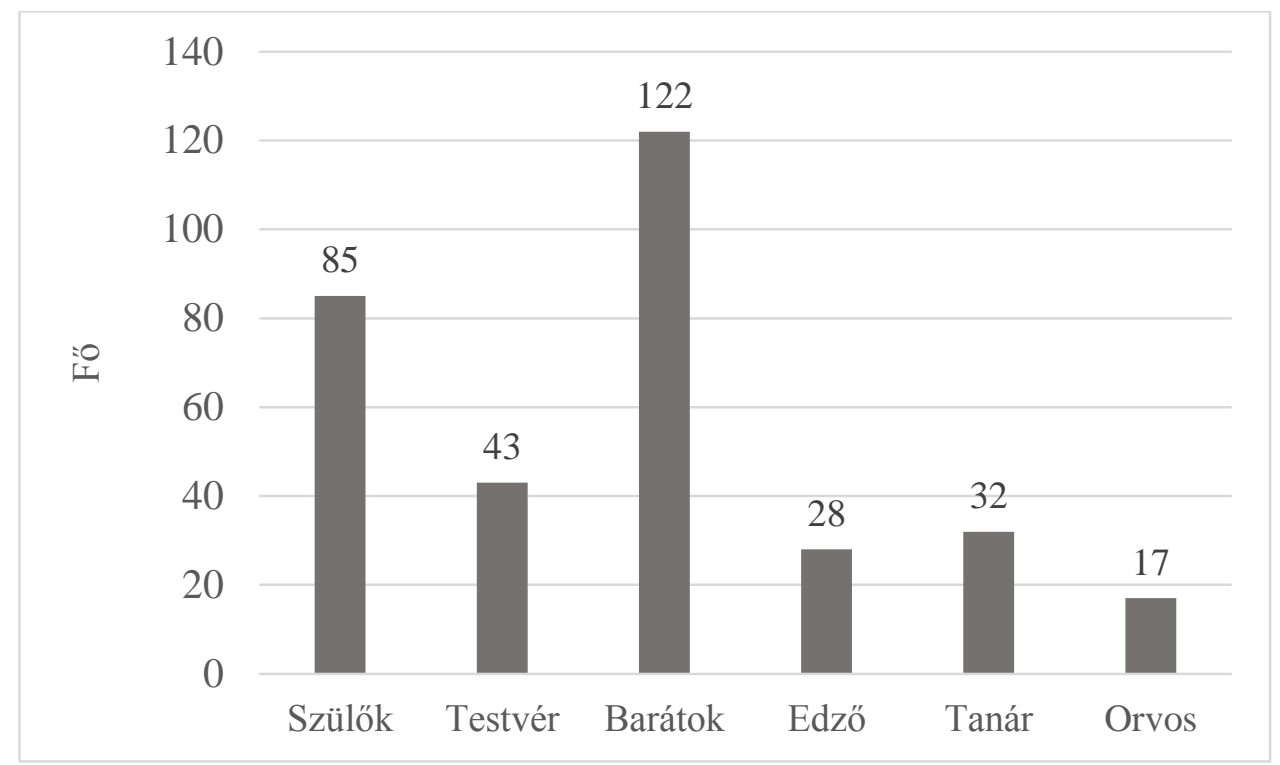

2. ábra. Sportra motiváló személyek

A legtöbb személytől, ha megkérdezik, hogy miért nem sportol, azt a választ kapjuk, hogy amiatt, mivel nincs rá ideje. Erre a problémára lehetne egy megoldás, ha a munkahelyek/ iskolák/ egyetemek több sportrendezvényt, sportolási lehetőségeket biztosítanának. A kitöltők 71,1\%-a (342 fö) örülne, ha több lehetôsége lenne a munkahelyen/ iskolában/ egyetemen a testmozgásra (3. ábra). A sporttól való távolmaradás okaként az Uniós felmérés (Eurobarométer, 2018) vagy más hazai kutatás is az időhiányt hozta ki első helyen (Balatoni et al., 2019).

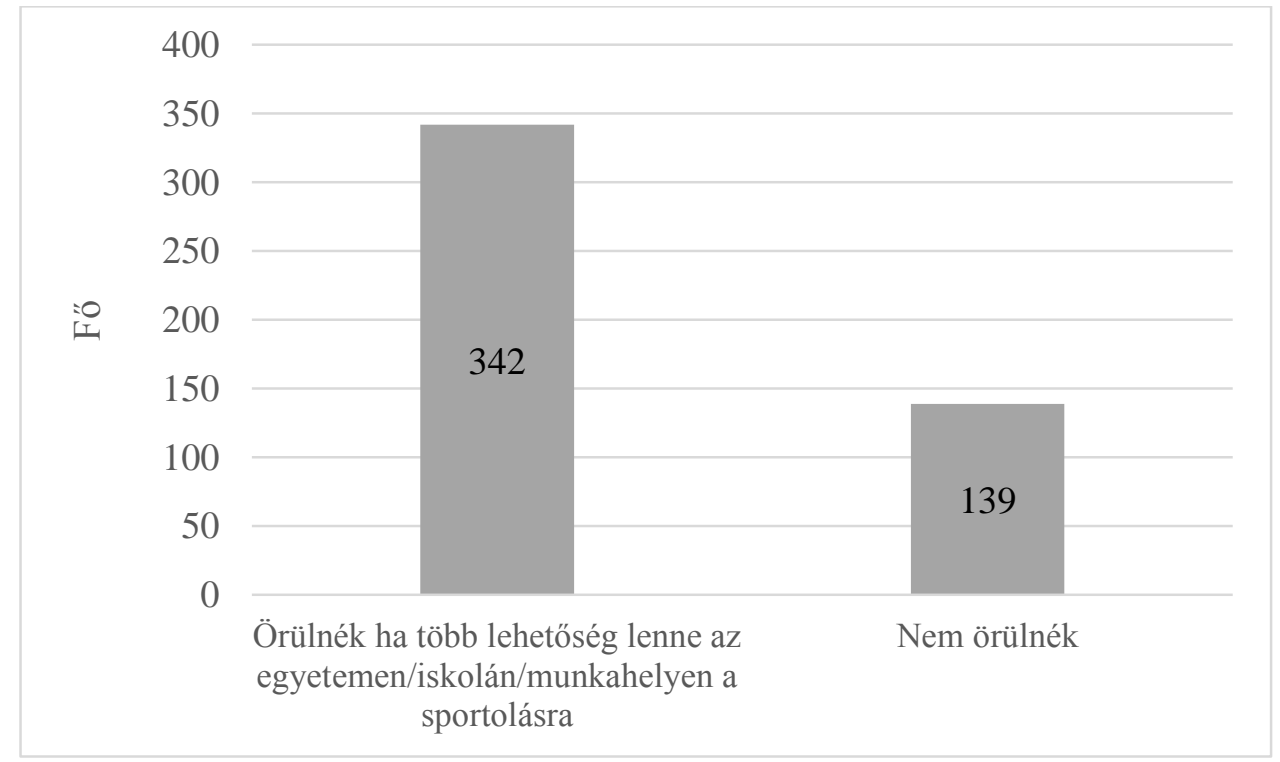

3. ábra. Sportnapokra való nyitottság eredményei

\section{Köveztetések és javaslatok}

A magyar fiatal felnőttek sportolási és sportmotivációs szokásait vizsgáltuk (n=481). A kutatásunk megállapította, hogy a fiatal felnőttek $71,1 \%$-a végez a testnevelés órán kívüli heti valamilyen rendszerességű szabadidős sportot, melynek időtartama minimum fél óra. Ez az eredmény 
örvendetes, hiszen a hazai felnőtt lakosság sportolási szokásait alátámasztó adatok szerint a felnőtt lakosság nagy része, azaz 53\%-a nem végez semmilyen sporttevékenységet (Eurobarométer, 2018). A kutatások azt is bemutatják, hogy az életkor előrehaladtával egyre inaktívabb életet élünk, csökken a rendszeres sportolók aránya a magyar kutatások szerint (Boda et al. 2015; Juhász et al. 2015).

Fontos, hogy a fiatal felnôttek sportmotivációs kutatásának eredményeit, fel tudjuk használni arra, hogy minél kevesebb legyen a sportot abbahagyók aránya. A marketing kommunikációban tehát (Molnár, 2017a, 2017b) azokat a hívó szavakat vagy üzeneteket kell eljuttatni hozzájuk, mely a sportolási motivációban (egészség, boldogság, vonzó külalak, szórakozás, jó társaság) leginkább dominál (Molnár, 2020a, 2020b, 2020c).

\section{Köszönetnyilvánítás}

A publikáció elkészítését a GINOP-2.3.2-15-2016-00005 számú projekt támogatta. A projekt az Európai Unió támogatásával, az Európai Regionális Fejlesztési Alap társfinanszírozásával valósult meg.

\section{Hivatkozott források}

[1.] Agahi N. - Parker M. G. (2008): Leisure activities and mortality: does gender matter? Joumal of Aging and Health, 20 (7), 855-871. DOI: 10.1177/0898264308324631

[2.] Apor P. (2011): A cardiovascularis kockázat kapcsolata a fizikai aktivitással és a fittséggel [Measure of fitness and physical activity related to cardiovascular diseases and death]. Orvosi Hetilap, 2011 (152), 107-113. DOI: 10.1556/OH.2011.29022

[3.] Bácsné Bába É. - Ráthonyi G. - Müller A. - Ráthonyi-Odor K. - Balogh P. - Ádány R. Bács Z. (2020): Physical Activity of the Population of the Most Obese Country in Europe, Hungary. Frontiers in public health, 8, 1-8. DOI: 10.3389/fpubh.2020.00203

[4.] Balatoni I. - Szépné Varga H. - Müller A. - Kovács S. - Kosztin, Nikolett A. - Csernoch L. (2019): Sporting habits of university students in Hungary. Baltic journal of health and physical activity, 1 Suppl (2), 27-37. DOI: 10.29359/bjhpa.2019.suppl.2.05.

[5.] Baranyai Sz. - Ráthonyi G. (2019): Az e-sport és a fizikai aktivitás. In: Bácsné, Bába É. Müller, A. (szerk.): "Mozgással az egészségért" A fizikai aktivitás jelentösége a jövö munkavállalóinak egészségmegörzésében: Nemzetközi Konferencia és Workshop: Válogatott tanulmánykötet = "Movement for bealth" The importance of physical activity in health protection of future workers: International Conference and Workshop: Proceedings from the International Conference and Workshop. Debrecen: Debreceni Egyetem. pp. 81-85.

[6.] Bocsi V. (2019): Roma fiatalok szabadidős és magaskulturális mintázatai = High culture and leisure time patterns among Roma youth. In: Biczó G. (szerk.): Terepek és elméletek = Fields and Theories: A Lippai Balázs Roma Sakekollégium válogatott romológiai tanulmánygyüjteménye $=$ Selected Essayes from the Field of Romology by Lippai Balázs Romani College. Debrecen: Didakt Kft. pp. 6582.

[7.] Boda E. - Honfi L. - Bíró M. - Révész L. - Müller A. (2015): A szabadidő eltöltésének és a rekreációs tevékenységek vizsgálata egri lakosok körében. Acta Academiae Paedagogicae Agriensis Nova Series: Sectio Sport, 42, 49-62. 
[8.] Boda E. J. (2018): Examination of Adventure park consumers in therm of motivations and amount of leisure time. Acta Oeconomica Universitas Selye, 7 (2), 33-46.

[9.] Bujdosó, Z. ; Dávid, L. (2013): Extreme sports and other activities in tourism with special regard to the Mátra Mountain. Journal Of Physical Education And Sport, 13 (1), 39-45

[10.] Chomistek A. K. - Manson J. E. - Stefanick M.L. et al., (2013): Relationship of sedentary behavior and physical activity to incident cardiovascular disease: results from the Women's Health Initiative. J Am Coll. Cardiol, 61, 2346-2354. DOI: 10.1016/j.jemermed.2013.07.008

[11.] European Commission. Special Eurobarometer 412 - Sport and Physical Activity. 2014. Letöltés dátum: 2020. szeptember 2.forrás: https://ec.europa.eu/health//sites/health/files/nutrition_physical_activity/docs/ebs_412_ en.pdf]

[12.] European Commission. Special Eurobarometer 472 - Sport and physical activity. 2017. Letöltés dátuma: 2020. szeptember $2 . \quad$ forrás: file://C:/Users/user/Downloads/ebs_472_en\%20 (7).pdf. [Accessed on 2 September, 2020].

[13.] Fletcher A. C. - Nickerson P. - Wright K. L. (2003): Structured leisure activities in middle childhood: Links to well- being. Journal of community psychology, 31 (6), 641-659. DOI: 10.1002/jcop.10075

[14.] Galán A. - Rákó E. - Szabó Gy. (2018): A virtuális világ veszélyei és a gyermekvédelem aktuális kérdései. Különleges Bánásmód, 4 (4), 61-72.

[15.] Hidvégi P. - Bíró M. - Müller A. - Váczi P. (2017): Testnevelési program a munkahelyi egészségfejlesztésben. Acta Academiae Paedagogicae Agriensis Nova Series: Sectio Sport, 44, 115138.

[16.] Juhász I. - Kopkáné, Plachy J. - Kiszela K. - Bíró M. - Müller A. - Révész L. (2015): Időskorúak rekreációs fizikai aktivitásának hatása a kardiorespiratorikus rendszerre. Magyar Sporttudományi Szemle, 16 (63), pp. 4-8.

[17.] Kruk J. (2009): Physical activity and health. Asian Pac J Cancer Prev. 10, 721 - 728.

[18.] Laoues N. - Dobay B. - Müller A. (2019): Examination Of The Leisure Time-Related Consumption Habits Of Young People With Disabilities With Special Emphasis On Sports. Selye E-Studies, 10 (2), 34-45.

[19.] Law M. - King G. - King S. - Kertoy M. - Hurley P. - Rosenbaum P. - Hanna S. (2006): Patterns of participation in recreational and leisure activities among children with complex physical disabilities. Developmental Medicine \& Child Neurology, 48 (5), 337-342. DOI: $\underline{10.1017 / \mathrm{s} 0012162206000740}$

[20.] Lengyel A. - Kovács S. - Müller A. - Lóránt D. - Szőke Sz. - Bácsné Bába É. (2019): Sustainability and Subjective Well-Being: How Students Weigh Dimensions. Sustainability, 11 (23), 6627. DOI: $10.3390 /$ su11236627

[21.] Lengyel A. (2016): Tourism, meditation, sutainability. Apstract - Applied Studies in Agribusiness and Commerce, 10 (1), 81-91. DOI: 10.19041/apstract/2016/1/11

[22.] Lenténé P. A. - Hidvégi P. - Tatár A. - Pucsok J. M. - Biró M. (2018a): Recreational potential of the northern great plain region in Hungary. In: Jaromír, Šimonek; Beáta, Dobay (szerk.) Sport science in motion: Proceedings from the scientific conference. Śportová veda v pobybe: recenzovany zbornike vedeckých a odborných prác z konferencie. Mozgásban a sporttudomány: válogatott tanulmányok a konferenciáról. Komárno: Univerzita J. Selyeho. pp. 218-226.

[23.] Lenténé Puskás A. - Tatár, A. - Lente L. - Pucsok, J. - Bíró M. - Hidvégi P. (2019): A sport és wellness elemek megjelenése az Észak- alföldi régió három-, négy- és ötcsillagos szállodáinak kínálatában. In: Bácsné Bába É. - Müller A. (szerk.): "Mozgással az egészségért" A 
firikeai aktivitás jelentösége a jövö munkavállalóinak egészségmegörzésében: Nemzetközi Konferencia és Workshop: Válogatott tanulmánykötet. Debrecen: Debreceni Egyetem. pp. 204-215.

[24.] Lenténé Puskás A. - Biró M. - Dobay B. - Pucsok J. M. (2018b): A szabadidő sportolás kínálati elemeinek, és szolgáltatásainak vizsgálata Magyarország Észak-alföldi régiójának szállodáiban. Selye E-Studies, 9 (1), 13-21.

[25.] Manson J.E. - Hu F.B. - Rich-Edwards J.W. - Colditz, G. A. - Stampfer, M. J. - Willett, W.C. - Speizer, F. E. - Hennekens, C. H. (1999): A prospective study of walking as compared with vigorous exercise in the prevention of coronary heart disease in women. $N$ Engl J Med, 341 (9), 650-658. DOI: $10.1056 /$ nejm199908263410904

[26.] Mező F. - Mező K. - Mező L.D. (2018): Képességfejlesztő játékok az IPOO-modell aspektusából: a fejlesztésbe integrált diagnosztika lehetősége. Különleges Bánásmód, 4 (2), 55-66.

[27.] Molnár A. (2019): Fitnesz trendek az egészség szolgálatában. In: Bácsné, Bába É., Müller, A. (szerk.) "Mozgással az egészuégért" A fizikiai aktivitás jelentösége a jövő munkavállalóinak. egészségmegörzésében: Nemzetközi Konferencia és Workshop: Válogatott tanulmánykötet. Debrecen: Debreceni Egyetem. pp. 113-120

[28.] Molnár E. (2017a): Kommunikáció, meggyózés, reklám. Szolnok: Alumni Kiadó.

[29.] Molnár E. (2017b): Korabeli magyar reklám és psæichológia. Szolnok: Alumni Kiadó.

[30.] Molnár E. (2012): Supervision in social work: experiences as a college supervisor of social worker training. Economica, 5, 2. különszám, 29-35.

[31.] Molnár E. (2020a): The role of empathy, anxiety and personality in purchasing decisions caused by advertisin. Annals of the University of Oradea. Economic Science, 29 (1), 376-386.

[32.] Molnár E. (2020b): The role of momentary and sustained emotional arousal level in advertising-infulenced and non-influenced purhasing decisions. Cross-cultural Managament Journal, 22 (1), 67-78.

[33.] Molnár, E. (2020c): The Role of the High Emotional Arousal Level in Purchasing Decisions Caused by Advertisements. SEA - Practical Application of Science, 8 (23), 235-241.

[34.] Müller A. - Bácsné Bába É. - Gabnai Z. - Pfau, C. - Pető K. (2019): A fitnesztrendek és új típusú mozgásformák társadalmi és gazdasági aspektusai. Acta Carolus Robertus. 9 (2), 109-122. DOI: $10.33032 /$ acr.2019.9.2.109

[35.] Müller A. - Bácsné Bába É. - Pfau, C. - Molnár A. - Laoues-Czimbalmos N. (2019): Extrém sportfogyasztás vizsgálata egy kutatás tükrében. International Journal of Engineering And Management Sciences / Müszaki és Menedzsment Tudományi Közlemények, 3 (4), 135-142. DOI: 10.21791/ijems.2019.3.13.

[36.] Müller A. - Bácsné Bába É. (2018): Az egészséges életmód és a sport kapcsolata. Létavértes: Létavértes SC'97 Egyesület.

[37.] Müller A. - Bíró M. - Bodolai M. -Hidvégi P. - Váczi P. - Dávid L. - Szántó Á. (2017): 2016os fitnesztrendek helye és szerepe a rekreációban. Acta Academiae Paedagogicae Agriensis Nova Series: Sectio Sport, 44, 91-102.

[38.] Müller A. - Bolega S. - Gabnai Z. - Bácsné Bába É. - Pfau, C. (2018): A BMX, és égyéb extrém sportok választásánák motivációs tényezői. International Journal of Engineering And Management Sciences / Müszaki és Menedðsment Tudományi Kǫ̈lemények, 3 (4), 426-441. DOI: 10.21791/ijems.2018.4.35.

[39.] Thompson W. R. (2020): Worldwide survey of fitness trends for 2020. ACSM'S Health \& Fitness Journal, 23 (6), 10-18. DOI: $10.1249 /$ FIT.0000000000000526

[40.] Verghese J. - Lipton R. B. - Katz M. J. - Hall C. B. - Derby C. A. - Kuslansky G. - Buschke H. (2003): Leisure activities and the risk of dementia in the elderly. New England Journal of Medicine, 348 (25), 2508-2516. DOI: 10.1056/neimoa022252 
Kinczel A. - Bácsné Bába É. - Molnár A. - Laoues-Czimbalmos N. - Müller A.

\section{Szerzők}

\section{Kinczel Antonia}

Sport- és Rekreációszervezés

II. Évfolyam

Debreceni Egyetem, GTK

antokincz@gmail.com

Prof. Dr. Bácsné Prof. Dr. Bába Éva

egyetemi tanár

Debreceni Egyetem, GTK

bacsne.baba.eva@econ.unideb.hu

Molnár Anikó

Sportközgazdász hallgató

II.. Évfolyam

Debreceni Egyetem, GTK

miller.e.annie@gmail.com

Dr. Müller Anetta

egyetemi docens

Debreceni Egyetem, GTK

muller.anetta@econ.unideb.hu

Laoues-Czimbalmos Nóra

tanársegéd

Debreceni Egyetem, GYGYK

laoues.nora@ped.unideb.hu 